\title{
Den ortodokse kirke i russisk (udenrigs)politik
}

Christian Gottlieb

\section{Efter Sovjetunionens sammenbrud er den Russisk- ortodokse Kirkes netværk vokset eksplosivt. Kirken har også store udenrigspolitiske ambitioner, der hidtil mest har påvirket Ukraine}

I de sidste år inden Sovjetunionens sammenbrud omfattede den Russisk-ortodokse Kirke (ROK) knap 7.000 sogne inden for unionens territorium. 20 år og radikale omvæltninger senere er det aktuelle tal nu over 29.000 sogne, som betjenes af lidt over 30.000 præster og diakoner. I 1988 var der 21 fungerende klostre; i dag er der lidt over 800. Der var i 1988 ingen ortodokse søndagsskoler og heller ingen ortodokse universiteter; i dag er der ca. 11.000 søndagsskoler og tre universiteter.

Som disse tal demonstrerer, er det ingen overdrivelse at hævde, at ROK i denne periode har gennemgået en enorm institutionel vækst, som på flere måder er bemærkelsesværdig. På baggrund af 70 års vedholdende og til tider ekstremt brutal forfølgelse og i betragtning af den dybe kri- se, som unionens sammenbrud efterlod det postsovjetiske samfund i, er en sådan vækst ingen selvfølge. Det ses fx i det fhv. Østtyskland, hvor 40 års socialisme har været nok til næsten at udrydde den evangeliske kirke, som ikke viser det mindste tegn på genopstandelse.

I modsætning hertil står den udvikling, som de nævnte tal angiver et ydre mål for, og som på mindre end to årtier har bragt ROK fra en status som en kuet, underdanig organisation på tålt ophold i samfundets udkant til en stor, selvsikker og højt profileret spiller i dagens Rusland. Som sådan er ROK formentlig det mest markante eksempel på den renæssance, som religion i almindelighed har oplevet siden socialismens sammenbrud.

En så markant vækst i synlighed og tilstedeværelse kan ikke undgå at 
sætte sit præg på det samfund, den udfoldes i, og spørgsmålet om ROK's mulige eller faktiske politiske rolle er da også blevet stillet gentagne gange - af vestlige iagttagere ofte med en vis bekymring over den sammenblanding af religion og politik, som synes at være tilfældet.

Spørgsmålet vil også blive stillet her, dog mindre af bekymring end af interesse, dels for den aktuelle udenrigspolitiske situation, dels for det større perspektiv, som situationen åbner: Hvor Vesteuropa i almindelighed helt af sig selv synes i færd med at afvikle sin kristne arv, er det påfaldende, at der i Rusland efter 70 års tvangssekularisering gøres et så omfattende forsøg på at genoplive den. Det er set med denne iagttagers øjne ikke kun bekymrende.

At ROK's ledelse er yderst bevidst om sin nye magtfulde position og $\mathrm{i}$ stigende grad er parat til at udnytte den til at påvirke det postsovjetiske russiske samfund i ortodoks retning, har længe stået klart af talrige officielle dokumenter og udtalelser af højtstående repræsentanter for ROK. Klarest kommer dette til udtryk i et officielt konstituerende dokument, som under titlen Principperne for den Russisk-Ortodokse Kirkes Sociale Koncept blev vedtaget på ærkebispekoncilet i august 2000.

Ved den lejlighed vedtog man desuden en ny statut for ROK og kanoniserede den sidste russiske tsar, Nikolaj II, og hans familie. I dette dokument, der kan betragtes som
ROK's sociale og politiske doktrin (herefter: Doktrinen), tager kirken principiel stilling til sit forhold til samfundet. I seksten punkter præsenteres først kirkens grundlæggende teologiske position og derpå dens officielle holdning til flg. spørgsmål: Kirke og nation; kirke og stat; kristen etik og verdslig ret; kirke og politik; arbejdet og dets frugter; ejendom; krig og fred; kriminalitet; personlig og samfundsmæssig moral; folkesundhed; bioetik; økologi; verdslig videnskab og kultur; kirken og verdslige massemedier samt problemer om globalisering og sekularisme.

Som det fremgår af disse punkter, har Doktrinens forfattere åbenlyst bestræbt sig på at komme hele vejen rundt i spektret af vigtige samfundsspørgsmål og problematikker, som åbenlyst er fyldt af politiske aspekter. Skønt ikke alle punkter behandles lige klart og konkret, giver Doktrinen som helhed dog et fyldigt indtryk af ROK's teologiske grundopfattelse og generelle holdning til den moderne verden.

\section{Slavofil genrejsning}

Karakteristisk for denne holdning er ikke mindst, hvor tydeligt den er præget af den russiske religionsfilosofiske tradition, som begyndte i 1840'erne med de såkaldte slavofile tænkere og siden har været repræsenteret af tænkere som bl.a. Vladimir Solovjov (1853-1900), Sergij Bul- 
gakov (1871-1944) og Nikolaj Berdjaev (1874-1948), men også af forfattere som Fjodor Dostojevskij (1821-81) og Aleksandr Solsjenitsyn (1918-2008). Et af flere gennemgående træk i denne tradition (der som helhed dog på ingen måde er entydig), er den stadige hævdelse af Ruslands slaviske og ortodokse identitet som noget, der på selvstændig, original og positiv vis adskiller Rusland fra 'Europa' eller 'Vesten'.

Set i dette lys er Rusland i kraft af sin ortodokse arv traditionelt forstået som bevarer af den autentiske kristendom, der i Vesten for længe siden er blevet forvansket af den grundlæggende rationalisme, som altid har præget vestlig tænkning og praksis, også om kristendom. Det er bl.a. denne rationalisme, der i moderne tid er årsagen til den materialisme og ateisme, åndløshed og splittelse, som ifølge denne tankegang stadig præger Vesteuropa, - men som i løbet af det 20. århundrede også har trukket sit katastrofale destruktive spor hen over Rusland i skikkelse af det sovjetiske eksperiment.

Som antydet har den intellektuelle tradition, som anes bag Doktrinens tekst, i høj grad karakter af en kulturkritik, der vendes imod vanlige vestlige forestillinger om fx adskillelse af stat og kirke og af religion og politik, om religion som en privatsag, universelle menneskerettigheder, pluralisme m.m. Mest fundamentalt anfægtes endda selve grundforestillingen om det sekulære, prin- cipielt religionsneutrale samfund. Vel anerkendes den gældende adskillelse af stat og kirke (som nedfældet i den Russiske Føderations forfatning af 1993) såvel som ikkereligiøse menneskers ret til at gøre deres holdning gældende, men Doktrinen lægger ikke skjul på, at målet i sidste ende er et andet. ROK må for sit vedkommende stræbe efter, at 'kristne værdier' lægges til grund for samfundsmæssige beslutninger på både nationalt og internationalt plan og insistere på legitimiteten af en religiøst baseret verdensanskuelse.

At denne målsætning ikke blot er retorik, er siden blevet bekræftet ikke mindst af kirkens udtrykkelige og gentagne bestræbelser på at genoplive det såkaldte 'symfonia'-princip. I dette begreb om 'samklang' mellem verdslig og åndelig magt udtrykkes det overleverede byzantinske ideal om det harmoniske forhold mellem kejser og patriark, stat og kirke, som har været gældende siden 530'erne.

I modsætning til Vesten, hvor dette forhold i teori og praksis ofte har været præget af konkurrence, om ikke ligefrem konfrontation, forudsætter 'symfonien' et nært samarbejde mellem stat og kirke. Ganske vist understreger ROK ofte, at stat og kirke skal afholde sig fra indblanding i hinandens respektive sfærer, og kirken lægger stor vægt på sin nyvundne selvstændighed (som ikke har været større siden Peter den Store gjorde ROK til en statskirke i be- 
gyndelsen af 1700-tallet). Samtidig kræver symfonien dog, at stat og kirke positivt arbejder med hinanden som to ligeværdige aktører. På det oprindelige byzantinske grundlag, som videreførtes i Rusland, fordi de i princippet var engageret i samme teokratiske projekt til fremme af gudsrigets komme; i den aktuelle situation snarere fordi ROK tilsyneladende håber på atter at se staten engageret om ikke ligefrem i et teokrati, så dog i hævdelsen af ortodoksien som det russiske samfunds Leitkultur.

I denne retning trækker også ROK's bidrag til udbredelsen af det langt nyere begreb om den 'russiske verden' (Russkij mir), som er blevet lanceret i løbet 2000-tallet. Dette begreb er ganske vist ikke kun specifikt kirkeligt, men forstås som et mere alment civilisationsbegreb om det folkelige og kulturelle fællesskab, som er blevet til inden for rammerne af det 'historiske Rusland', dvs. først og fremmest Rusland, Hviderusland og Ukraine, der forstås som tæt sammenknyttede lande og folk. Da de alle har været stærkt præget af ortodoksien, danner disse lande en særlig ortodoks civilisation, et 'civilisatorisk rum', som ROK ser sig som selvskreven repræsentant for. Også her høres ekkoerne fra tidligere tiders slavofile, måske endda panslavistiske, forestillinger ganske tydeligt.

Som de ovennævnte tal demonstrerer, er det en temmelig stor og vidstrakt organisation, der står til rå- dighed for udbredelsen af disse principper og holdninger. ROK's 29.000 sogne er spredt ud over kirkens såkaldte 'kanoniske territorium', dvs. det område inden for hvilket kirkens ledelse, Moskva patriarkatet, udøver den højeste kirkelige myndighed.

\section{Moskva patriarkatet}

Dette enorme område er næsten sammenfaldende med de tidligere sovjetiske grænser, med undtagelse af Armenien og Georgien, men til gengæld inklusive de ortodokse i kirker i Kina og Japan. Trods Sovjetunionens opløsning bevares således i kirkelig sammenhæng stadig en struktur, der har Moskva som centrum og øverste autoritet. Som den aktuelle udvikling viser, er dette en væsentlig faktor i ROK's mulighed for at udøve politisk indflydelse.

I forhold til udlandet varetages relationerne først og fremmest af ROK's Afdeling for Ydre Kirkelige Forbindelser, der fungerer som en slags kirkeligt udenrigsministerium, for tiden under ledelse af metropolit Ilarion af Volokolamsk. Under denne institutions auspicier mødes kirkens overhoved, patriark Kirill, og andre repræsentanter for ROK hyppigt med både kirkelige og ikkekirkelige ledere, fremmede landes stats- og regeringschefer, ministre, ambassadører eller fremtrædende kulturpersonligheder og økumeniske forbindelser. Afdelingen repræ- 
senterer også ROK i forhold til internationale organisationer som FN og EU.

Særlig interesse har selvsagt forbindelser til andre ortodokse kirker og lande, som fx Bulgarien, Rumænien, Grækenland, Serbien og Georgien, i forhold til hvilke ROK tydeligvis er sig bevidst at spille en ledende rolle i kraft af sin status som det største ortodokse kirkesamfund.

Ud over sin egen afdeling for eksterne forbindelser er ROK også $\mathrm{i}$ 2010 etableret i en formaliseret samarbejdsrelation med den Russiske Føderations Udenrigsministerium, dels i skikkelse af en arbejdsgruppe til udvikling af dette samarbejde, dels i skikkelse af kirkelig deltagelse i Udenrigsministeriets Diplomatiske Akademis kurser for russiske diplomater, som bl.a. får lejlighed til at mødes med patriarken.

Iflg. ROK's oplysninger fokuserer kirken i disse sammenhænge i høj grad på russkij mir-konceptet, dvs. på indsatsen over for den store og vidtstrakte russiske diaspora, der ses som en organisk del af den russiske verden. Det erklærede formål er at arbejde for bevarelsen af den russiske verdens nationale og kulturelle tradition og 'civilisatoriske helhed'. Som et led i denne indsats har ROK i november 2009 også indgået en formel samarbejdsaftale med Russkij Mir Fonden, der i 2007 blev dannet som et verdsligt russisk kulturinstitut, der skal udbrede kendskabet til russisk sprog og kultur.
Fonden har i skrivende stund oprettet 69 lokale udenlandske repræsentationer i udenlandske byer med en større russisk emigrantbefolkning.

\section{Evnen og viljen}

At ROK har både vilje, motivation og i stigende grad også evne til at udøve politisk indflydelse, er således indlysende. Vanskeligere at bedømme er imidlertid, hvor stor en rolle, dens indsats faktisk spiller. Som et bidrag til belysningen heraf følger til slut en kort præsentation af en sag, som i skrivende stund er under udfoldelse. Det drejer sig om det vanskelige forhold mellem Rusland og Ukraine, hvor alle de her nævnte temaer kommer i spil.

I kølvandet på Ukraines selvstændighedserklæring i 1991 opstod også spørgsmålet om den Ukrainske Ortodokse Kirkes (UOK) tilhørsforhold til Moskva patriarkatet, som også tidligere har været omstridt. Resultatet blev, at dele af UOK med den lokale leder, metropolit Filaret, i spidsen i 1992 forlod Moskva patriarkatet og dannede sin egen selvstændige ukrainske kirke med eget patriarkat i Kijev, hvor Filaret i 1995 blev indsat som patriark. Som repræsentant for måske ca. 20 pct. af de troende i Ukraine var der tale om en mindre, men dog væsentlig del af den ortodokse kirke, om end den moskva-loyale del af kirken fortsat anslås at repræsentere over halv- 
delen af de troende. Dette skridt er af Moskva patriarkatet blevet opfattet som utvetydigt fjendtligt og kirkesplittende, hvorfor ROK nægter at anerkende Kijev patriarkatet som en autentisk ortodoks kirke. Filaret selv blev ekskommunikeret i 1997.

Sagen har siden været kontroversiel og en stående del af det spændte spørgsmål om Ukraines forhold til Rusland.

\section{Åben fjendtlighed}

Den seneste udvikling har kun kunnet bekræfte dette. I en udtalelse i slutningen af januar 2011 har den aldrende patriark Filaret fremsat den markante påstand, at ROK's ledelse 'inden sommerens komme' agter at 'ødelægge' Kijev patriarkatet og indlemme den Kijev-loyale del af UOK under sin jurisdiktion. Med dette formål er Moskva-loyale præster angiveligt allerede i gang med at 'overtage' kirker, der hidtil har hørt under Kijev patriarkatet, og at overtale de lokale præster til at vende tilbage til Moskva.

Denne aktion ses som et led i en overordnet politik, der skal styrke båndene mellem Ukraine og Rusland. Iflg. en anden repræsentant for Kijev patriarkatet, biskop Evstratij, har Rusland aldrig anerkendt det uafhængige Ukraine, som tværtimod anses for tæt knyttet til den 'russiske verden', som både ROK og det russiske udenrigsministerium ofte henviser til. Ifølge denne udlægning forsøger patriark Kirill at udnytte den kirkelige strid til også at anstifte en verdslig politisk strid, der kan føre til intet mindre end den ukrainske stats sammenbrud, således at den atter vil kunne forenes med Rusland (i interview ved Oksana Klimontjuk af 28.1. 2011).

Hvor meget realitet der er i sådanne udtalelser er svært at bedømme. Åbenlyst vidner de dog om, at ROK af Moskva-kritiske røster i Ukraine opfattes som en magtfuld spiller, som er i stand til at udøve reel politisk indflydelse til fordel for den siddende russiske regering.

Disse udtalelser ligger i så henseende i klar forlængelse af de protester, som tidligere udløstes fra ukrainsk side af patriark Kirills besøg i Ukraine i sommeren 2009 og igen i forbindelse med hans deltagelse $\mathrm{i}$ indsættelsen af Ukraines nye præsident Viktor Janukovitj i februar 2010. Selv om Kirill ved begge lejligheder forsikrede ikke at have nogle politiske hensigter, blev hans blotte tilstedeværelse uundgåeligt tolket $\mathrm{i}$ dette lys.

På baggrund af de principper og holdninger, som ROK giver udtryk for, er det heller ikke nemt at lade være.

Christian Gottlieb er leder af H.M. Dronningens Håndbibliotek. Han er dr. theol. og $i$ perioder ekstern lektor $i$ kirkehistorie ved Københavns Universitets Teologiske Fakultet. 